DOI 10.31558/2307-2318.2020.4.4
УДК $331.5+331.42$
JEL: J23

Середа Г.В.,

кандидат економічних наук, доцент кафедри менеджменту та поведінкової економіки Донецького національного університету імені Василя Стуса

ORCID: 0000-0001-9222-1887

g.sereda@donnu.edu.ua

Магас M.A.,

Донецького національного університету імені Василя Стуса mahas.m@donnu.edu.ua

\title{
ПРОГНОЗУВАННЯ МАЙБУТНІХ ЗМІН НА РИНКУ ПРАЦІ УКРАЇНИ ВНАСЛІДОК ПАНДЕМІЇ COVID-19
}

Статтю присвячено оцінизі стану ринку пращуі та прогнозуванню майбутніх змін в сфері праці під впливом пандемії коронавірусу. В результаті аналізу закордонних та вітчизняних джерел інформації, статистичних даних щзодо показників запланованого вивільнення прачівників, показників зареєстрованого та фактичного безробіття в Україні, зроблено висновок, щзо пандемія COVID-19 призведе до глобальних змін на ринку праці, та в характері праці, а тому роботодавиялм та працівникам потрібно адаптуватись під нові умови життедіяльності. Для иього окреслені основні напрями цих змін та продемонстровано кращі практики адаптащіi підприємств до них. Доведено, щзо карантинні заходи спричинили більш інтенсивне скорочення малокваліфікованого персоналу, переважно, робітничих професій, та незворотні процеси поширення дистанційної форми організаџіï праці. Це потребуватиме подальшого нормативного регулювання дистанційної роботи, інтенсифікації програм перекваліфікації вивільнюваних людських ресурсів, посилення їх сочіального захисту, підтримки роботодавців, особливо, малого бізнесу, в період коронакризи.

Ключові слова: ринок праці, безробіття, дистанційна робота, циифровізація, COVID-19.

Рис. - 3, Табл. - 1, Літ. - 8.

Постановка проблеми. Пандемія гострої респіраторної хвороби, спричиненої коронавірусом COVID-19, стала тим фактором, який змусив весь світ переглянути не лише прогнози розвитку, свою короткострокову економічну та соціальну політику, але й по іншому підійти до формування власних пріоритетів на довгостроковий період. Уроки, винесені людством з початку цієї пандемії, можуть змінити не лише моделі управління у майбутньому, але і соціальну поведінку людства. 3 позиції сьогодення важко оцінити майбутні зміни i ще складніше спрогнозувати та спланувати короткострокову перспективу пристосування суб'єктів ринку праці.

Аналіз останніх досліджень і публікацій. Через новизну теми дане питання недостатньо досліджене. Проте окремі науковці та експерти уже почали вивчати його окремі аспекти. Серед них можна виділити Е. Лібанову та Т. Пашкіну, які досліджують стан та перспективи розвитку постпандемічного ринку праці. В зарубіжних країнах 
популярністю користується праця Ф. Закарії «10 Lessons for a Post-Pandemic World», в якій він висвітлив передбачення щодо стану економіки та іiі складових в результаті COVID-19.

Основною метою даної статті $\epsilon$ огляд та передбачення майбутніх тенденцій на постраждалому від карантину ринку праці, для можливості розробки напрямів покращення його стану та зменшення негативних наслідків для економічно активного населення.

Основна частина. Експерт з ринку праці Т. Пашкіна ще у вересні 2020 року вважала, що ситуація на ринку праці може повернутися до весняних показників (запровадження перших карантинних заходів) у разі розгортання другої хвилі пандемії. Адже нову кризу буде набагато важче пережити. Відомо, що до пандемії, в людей були незначні фінансові заощадження, а у разі другої хвилі пандемії, їх вже не буде в наявності. Нова криза може спричинити більш інтенсивне зростання безробіття та скорочення зайнятості до квітневих показників [1].

Ці прогнози підтвердилися даними офіційної статистики щодо запланованого вивільнення працівників (табл. 1). Порівняно з аналогічним періодом попереднього року, обсяги вивільнень зросли на 40\%. Відповідно, кількість офіційно зареєстрованих безробітних станом на 1 грудня 2020 року зросла на 41,5\%, досягнувши 408,8 тис осіб. Всього ж за період карантину (з 12 березня по 30 листопада) статус безробітного отримали 641,2 тис громадян. Найбільше заплановане вивільнення персоналу за абсолютними значеннями спостерігалося в групі фахівців та керівників, менеджерів майже $40 \%$ всіх вивільнюваних. Однак у порівнянні з обсягами запланованих вивільнень у 2019 році, найбільш інтенсивно (в 2 - 2,4 рази більше) скорочувався виробничий персонал - робітники з обслуговування, експлуатації та контролювання за роботою технологічного устаткування, складання устаткування та машин та кваліфіковані робітники з інструментом.

Таблиця 1

Інформація щодо запланованого масового вивільнення працівників (за професійними групами) [2]

\begin{tabular}{|c|c|c|c|c|}
\hline & \multirow{2}{*}{$\begin{array}{l}\text { Січень- } \\
\text { листопад } \\
2019 \text { p. } \\
\end{array}$} & \multirow{2}{*}{$\begin{array}{l}\text { Січень- } \\
\text { листопад } \\
2020 \text { р. } \\
\end{array}$} & \multicolumn{2}{|c|}{ Зміна значення } \\
\hline & & & $\%$ & $+(-)$ \\
\hline $\begin{array}{c}\text { Усього } \\
\text { з них: за професійними групами }\end{array}$ & 179737 & 2252240 & 14140,3 & 72503 \\
\hline $\begin{array}{l}\text { Законодавці, вищі державні службовці, керівники, } \\
\text { менеджери (управителі) }\end{array}$ & 35721 & 50955 & 142,6 & 15234 \\
\hline Професіонали & 46499 & 43690 & 94,0 & -2809 \\
\hline Фахівці & 35865 & 52353 & 146,0 & 16488 \\
\hline Технічні службовці & 6935 & 9166 & 132,2 & 2231 \\
\hline Працівники сфери торгівлі та послуг & 19693 & 30630 & 155,5 & 10937 \\
\hline $\begin{array}{l}\text { Кваліфіковані робітники сільського та лісового } \\
\text { господарств, риборозведення та рибальства }\end{array}$ & 945 & 767 & 81,2 & -178 \\
\hline Кваліфіковані робітники з інструментом & 9204 & 18643 & $\mathrm{y} 2,0 \mathrm{p}$. & 9439 \\
\hline $\begin{array}{l}\text { Робітники з обслуговування, експлуатації та } \\
\text { контролювання за роботою технологічного } \\
\text { устаткування, складання устаткування та машин }\end{array}$ & 11753 & 26628 & y $2,3 \mathrm{p}$ & 14875 \\
\hline Найпростіші професії та особи без професії & 13122 & 19408 & 147,9 & 6286 \\
\hline
\end{tabular}


В галузевому розрізі - найбільше постраждав ринок праці туристичної галузі та громадського харчування (кількість безробітних зросла на 84,4\% за період з січня по листопад 2020 року порівняно з аналогічним періодом минулого року; діяльність у сфері адміністративного та допоміжного обслуговування - на 49,7\%; оптова та роздрібна торгівля; ремонт автотранспортних засобів і мотоциклів - на 39,6\% та , як не дивно, інформація та телекомунікації - на 39,7\%. Лише в двох галузях чисельність безробітних зменшилась: у сільському та лісовому господарстві; в галузі водопостачання, каналізації, поводження з відходами, але не значно - в межах 2,2\%.

Рівень безробіття населення (за методологією МОП) у віці 15-70 років у I півріччі 2020 року порівняно з аналогічним періодом минулого року зріс з 8,5\% до 9,2\% робочої сили, а рівень зайнятості у критичному II кварталі 2020 скоротився на 3,4 процентних пункти або на 1 млн 89 тис осіб. [2] На думку багатьох експертів - безробіття в Україні вийде на допандемічний рівень - 8,2\% лише у 2024 році. Для відновлення втраченого потенціалу під час першої хвилі пандемії COVID-19 Україні потрібно буде від одного до двох років. Характер відновлення буде залежати від існуючих та нових карантинних заходів в Україні.

На нашу думку, в наступних роках можно очікувати появи нових тенденцій на ринку праці:

- посилення дистанційної зайнятості (робота з дому);

- результат праці стане важливішим за ії процес;

- зростання процесів оптимізації персоналу;

- виникнення проблеми безпеки особистої та корпоративної інформації;

- розвиток програм адаптації до змін, турботи про психічне здоров'я дистанційно працюючих;

- зміна великих офісних приміщень на менші за розміром об'єкти - платформи коворкінгу;

- прискорення цифровізації та автоматизації робочих процесів;

- зростання ролі держави на ринку праці;

- посилення значення гігієни праці та безпеки на підприємствах;

- погіршення соціальної взаємодії між людьми;

- проблема 3 працевлаштуванням молоді;

- пришвидшення процесів появи нових професій та робіт, видозміни чи зникнення застарілих.

Обгрунтуємо окреслені тенденції розвитку ринку праці.

Дистанційна зайнятість. Дистанційна робота створює багато нових можливостей, як для роботодавця, так і для працівника. Вона з'явилась 3 появою інформаційно-комунікаційних технологій, проте нагальної потреби у такій формі організації праці до 2020 року не виникало. Карантинні заходи майже по всьому світу змусили більшість офісних працівників перейти на дистанційну роботу, активно освоюючи он-лайн платформи для спільної роботи, сервіси відеозв'язку, електронні системи документообігу та соціальні мережі для створення корпоративних інформаційних просторів. Це дозволило сторонам соціально-трудових відносин оцінити всі переваги та недоліки дистанційної роботи. I хоча менеджери та працівники ще можуть відчувати певний дискомфорт від нестачі «живого спілкування», щільної «екранізації» роботи, проте, з огляду на переваги безпеки, технічних можливостей, значної економії адміністративних витрат на утримання офісів, вдалого задоволення потреб працівників в підтриманні балансу «робота-життя» ці негативні відчуття, 
скоріше будуть спрямовані в русло удосконалення технологій та правил дистанційної роботи.

Опитування свідчать, що багато компаній залишить віддалену роботу або комбінований графік $з$ тим, щоб 1-2 дні на тиждень люди приходили в офіс, а весь інший час працювали дистанційно. За опитуванням 50 українських компаній, проведеним з 04 по 12 травня 2020 року консалтинговою компанією KPMG, у зв'язку з карантинними заходами 96\% опитаних компаній в Україні перевели своїх співробітників на віддалену роботу; тільки 4\% вказали, що специфіка компанії не передбачає віддалену роботу (рис. 1). [3]

За опитуваннями у США троє 3 п’яти працівників, що працювали вдома під час карантину, воліли би працювати віддалено настільки довго, наскільки це є можливим, навіть після того, як картинні обмеження буде скасовано (за даними Gallup). Більше того, за даними Owl Labs, більше третини працівників погодяться на зниження заробітної плати до 5\% в обмін на можливість працювати віддалено хоча б частину часу; ще чверть заради цього піде і на 10\% зниження зарплати, а 20\% працівників погодяться і на ще радикальніші скорочення, аби лише працювати вдома. За даними опитування DigData, серед працюючих користувачів інтернету в Україні 39\% хотіли б працювати віддалено і після завершення карантину.
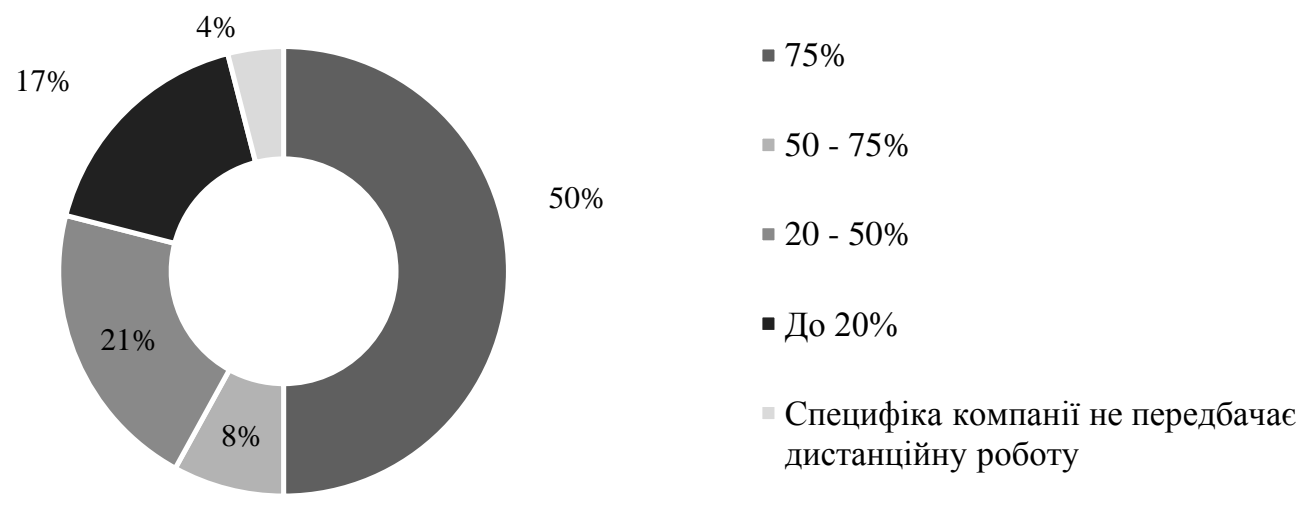

Рисунок 1. Відсоток працівників, переведених на дистанційну роботу [3]

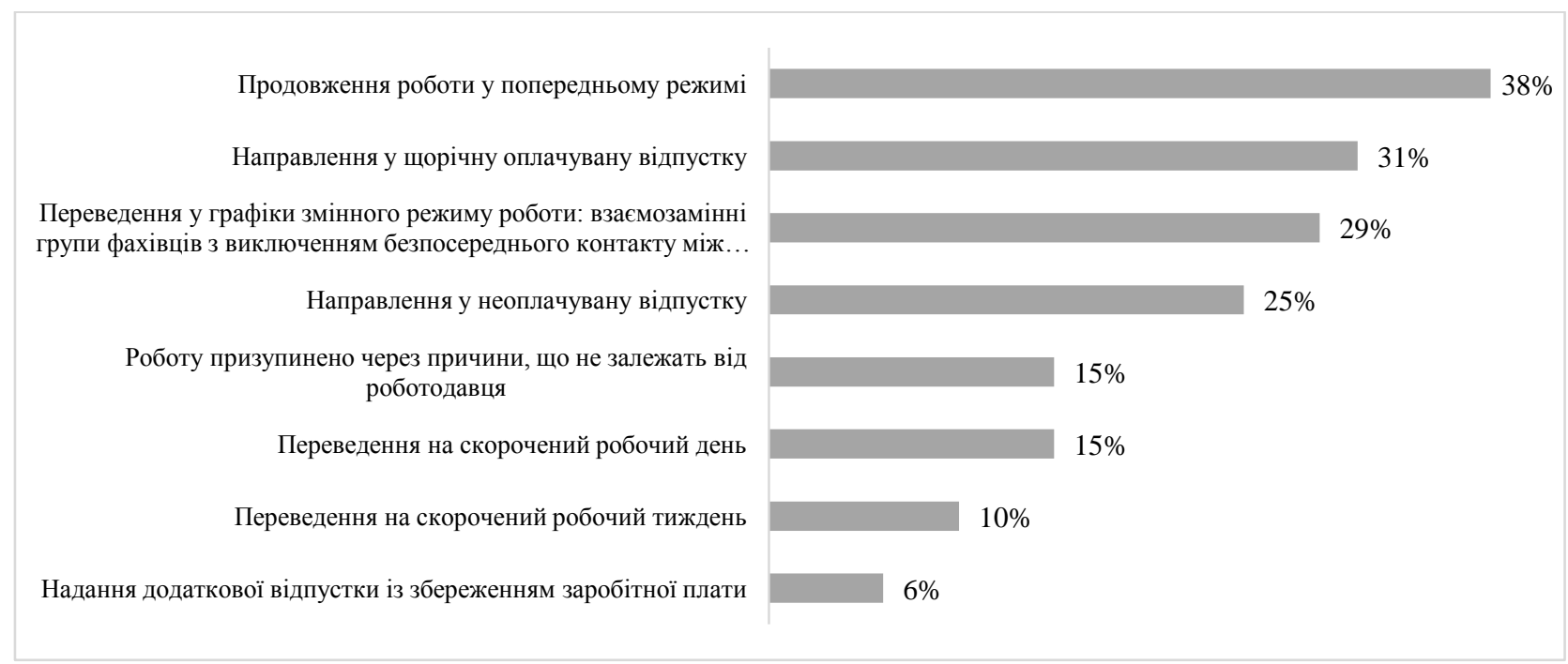

Рисунок 2. Зміни в організації праці в опитаних в травні 2020 року українських компаніях [3] 
Вiд 56\% до 87\% роботодавців у різних сферах готові залишати маркетинг, IT, HR, бухгалтерію, іноді продажі (особливо, онлайн) на віддаленому чи гнучкому графіку. Організації почали проводити онлайн-таунхоли (неформальні розмови про найважливіші справи), зустрічі в Zoom та об'єднувати команду спільними справами онлайн. За два місяці роботи у такому режимі багато компаній не помітила погіршення ефективності в роботі. Багато хто 3 працівників зазначив, що ефективність навіть зросла [5]. Директор з персоналу вітчизняної IT-компанії Softserve повідомила під час круглого столу, що продуктивність праці співробітників навіть зросла в середньому на 30\% через відсутність необхідності діставатись до офісу.

Таким чином, вважаємо, що цей вид праці буде й надалі поширюватись, розвиватись та удосконалюватись його нормативне регулювання на законодавчому рівні. Хоча вже в трудовому кодексі з'явилося більш широке, не обмежене правилами внутрішнього трудового розпорядку, трактування трудового договору на умовах дистанційної (надомної) роботи - ст.21, ст.60 КЗпП. Крім того, у зв'язку з розвитком дистанційної роботи, відкриється доступ до ринку праці деяким категоріям населення, які за інших умов мали менше можливостей для цього (батьки неповнолітніх дітей, самотні матері, люди старшого віку, особи 3 інвалідністю) та були економічно неактивними.

Прогнозовано слід очікувати зміни в системах оплати праці. Вже в цьому році кадровики організацій постали перед питанням, як табелювати працівників, які працюють дистанційно; як обліковувати робочий час працівників, які за медичними документами ще перебувають на лікарняних, однак фактично працюють у дистанційному режимі із застосуванням ІКТ. Вимушене поширення дистанційної роботи змінить, на нашу думку, переважання традиційної почасової оплати праці. Тепер головним в роботі працівника буде результат його діяльності, а не сам процес іiі виконання. Роботодавець, не зможе візуально контролювати, як саме працівник справляється з завданням, проте зможе оцінити результат його виконання. Отримають розвиток, на нашу думку, гібридні форми оплати праці на основі автоматичного обліку машинного робочого часу, диференційованого за видами діяльності (ефірний час наради, конференції, позаефірний час - аналітична та творча робота), та преміюванням за проєктним підходом - за аккордною системою по завершенню проєкту, продажу продукту, здачі замовлення, тощо.

Оптимізація персоналу. Розвиток та популяризація роботизації вже створили технічне підгрунтя масового обезлюднення виробничих площадок. I якщо раніше цей процес стримувався гуманістичними поглядами власників бізнесу та топ-менеджменту на збереження робочих місць, цінності людського капіталу, то в карантинних умовах ці міркування стали розкішшю для топ-менеджменту. У зв’язку з кризою, великі компанії розпочнуть переглядати потрібність тих чи інших людей для них. Це може призвести до значного скорочення працівників, які не являються суттєво важливими для компанії, тобто тих, хто не впливає на їі розвиток, прибуток. Це призведе до поширення безробіття, перш за все, в групі низькокваліфікованих співробітників, та збільшить навантаження на наявний персонал, що вже підтверджується даними табл.1.

Безпека даних роботодавців та персоналу. Через переведення трудової діяльності в цифровий простір може виникнути загроза втрати анонімних даних працівника та роботодавця. Через недобросовісність однієї зі сторін, або хакерської атаки на сервери організації, інформація може опинитись не в тих руках. Працівник може розпоряджатись таємною корпоративною інформацією фірми за межами свого робочого місця (з дому), що може призвести до передачі такої інформації третім 
особам. Так само роботодавець, володіючи анонімною інформацією про працівника, може використовувати іiі у власних цілях (наприклад, передавати торговельним організаціям чи рекрутинговим агенціям). Окреме питання постає щодо захисту прав інтелектуальної власності на винаходи, наукові твори та витвори мистецтва, промислові зразки, технології, які ще не встигли пройти процедури реєстрації. Питання захисту віртуальної інформації та даних потребує додаткового законодавчого врегулювання та технічно-програмного удосконалення за умов дистанційної роботи вже зараз.

Програми адаптації для дистанційно працюючих. Коронакриза та зміни у роботі викликали труднощі в більшості працівників, зазначається в дослідженні ЕМА Partners International. 78\% співробітників мають проблеми з балансом між роботою та сімейними обов'язками, 53\% зазначають, що їм важко перебувати в ізоляції та не мати живого контакту 3 колегами. Ще $48 \%$ повідомили про психологічний стрес, спричинений швидкими змінами та негативною інформацією у медіа. Експертка 3 організаційних трансформацій Оксана Семенюк зазначає, що чимало людей нарікають на те, що у віддаленій роботі стерлася межа між робочим часом та відпочинком. Тому в наступному році в HR-відділів з'явиться багато нової роботи щодо організації програм психологічної підтримки та залучення до команди таких працівників. Провідне місце в розробці заходів для адаптації дистанційників займуть IT-компанії. У них вже зараз відбуваються кулінарні шоу, вікторини, конкурси, «рейви», у форматі онлайн відеозустрічей [6].

Цікавою $\mathrm{e}$ well-being HR-програма підрозділу корпорації Beeline в Казахстані, спрямована на зниження відчуття тривожності працівників, створення кращих умов надомної роботи та збільшення залученості персоналу. Причиною їі розробки стали результати щотижневих скринінгів настрою співробітників, які до епідемії багатьом працівникам вважалися зайвою IT-забавкою, однак за умов епідемії трансформувались в потужний інструмент превентивної HR-аналітики. Для того, щоб покращити настрій співробітників, зняти тривожність за здоров'я (власне та близьких), перспективи збереження роботи, компанія відкрила власну Гарячу телефонну лінію та чат, найняла в штат лікарів та психологів, активізувала для працівників мобільний застосунок № stress, організувала групу швидкого реагування та волонтерів в режимі 24/7, які доставляли хворим продукти та ліки, особливо, у віддалені регіони, закупила програму медичного страхування для працівників, в тому числі у разі інфікування COVID-19 та розвитку пневмонії. Для полегшення віддаленої роботи була створена «Антивірусна програма», яка через спеціальну корпоративну соціальну мережу пропонувала співробітникам та членам їх сімей фітнес-марафони, книжкові клуби 3 обміну враженнями від прочитаного, ранкові стендап-шоу, кулінарні марафони, цікаві навчальні та розважальні рубрики для дітей, майстер-класи, рубрику для кіберспортсменів, спільноти фасилітаторів, коучей та психологів, тощо. Дієвою програмою для покращення настрою персоналу стала програми п’ятничних живих ефірів «Friday Talks» 3 н'юзмейкерами - топ-менеджерами корпорації. Особливу увагу компанія приділила навчанню працівників, організувавши серію вебінарів 3 відомими бізнестренерами та коуч-гуру та консультантами в рамках програми \#вебінаробіотик. Формат проведення дозволив значно розширити аудиторію слухачів. Така активна кадрова політика дала можливість компанії зберегти лідерські позиції на ринку послуг мобільного зв'язку Казахстану. [7]

Можна спрогнозувати, що епоха великих офісів закінчилася: компанії в різних країнах, у тому числі в Україні, вирішать, що до пандемії витрачали на оренду офісних 
площ занадто великі кошти. В офіс повернуться найнеобхідніші співробітники, інші продовжать працювати з дому, перейдуть на фріланс або на часткову зайнятість. Через такі нововведення офісні приміщення зменшаться в рази, а компанії заощадять кошти на оренду, які надалі зможуть витратити на розвиток власного персоналу.

Цифровізація та автоматизація процесів. На нашу думку, відбудеться ріст автоматизації виробництва та цифровізації бізнес-процесів, проте він буде повільним і нерівномірним у всіх сферах. Більшість компаній та установ під час пандемії зіткнулись із необхідністю діджиталізації своєї діяльності. Деякі компанії вже автоматизують процеси, впроваджують цифрові рішення, досліджують досвід закордонних компаній 3 метою працювати та отримувати прибуток незалежно від коронавірусних обставин. Вплив цифровізації на ринок праці спричинить, з одного боку, покращення умов роботи, створення нових робочих місць, а з іншого, посилить безробіття, оскільки значна частина населення працездатного віку буде не в змозі отримати необхідні знання для роботи, не зможе в короткий термін сприйняти нововведення.

Зростання ролі держсави на ринку праці. Вже сьогодні роботодавці звертаються за підтримкою до служби зайнятості, зокрема, за допомогою по частковому безробіттю на період карантину. Несуттєво (на $3,4 \%$ ) в умовах суттєвого (на $37,8 \%$ ) скорочення вакансій, зросла кількість послуг, що надаються Державною службою зайнятості; 3 них основна чатка припала на заходи пасивної політики зайнятості - виплату допомог (рис.2). Найбільше скоротилися обсяги залучення до громадських та інших тимчасових робіт та перенавчань безробітних - майже вполовину порівняно 32019 роком. В майбутньому захисний вплив держави може зростати, оскільки запаси фінансової стійкості бізнесу значно скоротилися.

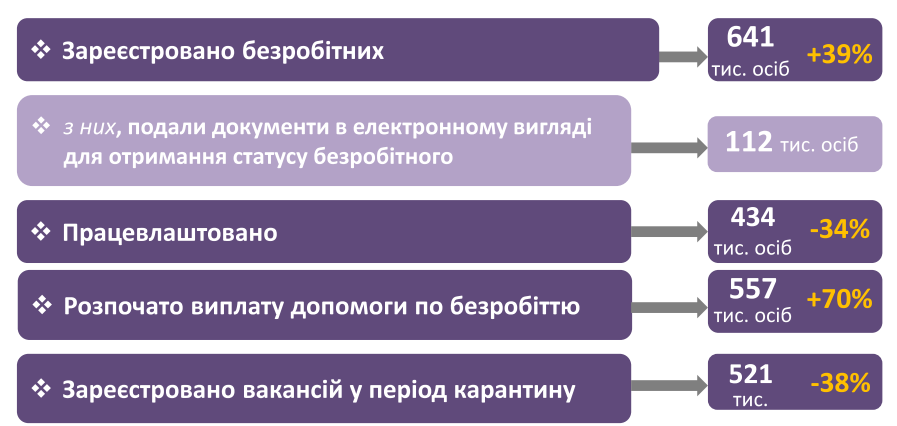

Рисунок 3. Надання послуг Державною службою занятості в період карантину [2]

Потребує детального вивчення проблема співвідношення ризиків та вгод від подальшого залучення праці іноземної робочої сили. Хоча вже зараз наявні розрахунки (S.Kozlovskyi et al., 2020), згідно до яких без трудових мігрантів валовий внутрішній продукт може впасти до 43\% в Італії, 45\% у Нідерландах, 37\% в Іспанії та 200\% у Швейцарії в 2020 році. [9]

Посилення значення гіхієни та безпеки праці на підприємстві. Оброблення приміщень, масочний режим, інфрачервоні термометри на постійній основі - ось, що може змінитись в організації праці підприємств у наступних роках. Деякі архітектори вже розробляють новий дизайн офісів з ліфтами без кнопок та 3 камерами, які скануватимуть персонал на стан їх здоров’я та встановлення їх особистості. 
Зміна соціальної складової. Заслужений економіст України Елла Лібанова вважає, що погіршаться соціальні відносини між людьми, через відсутність постійних комунікацій. Багато працівників вже зараз скаржуться на самотність та вигорання через переведення на дистанційну зайнятість. Для значної частини людей робоче середовище було місцем соціальних контактів, можливістю комунікувати один 3 одним, обмінюватись новинами [8].

Молодих людей, що мали б переходити від навчання до роботи, вже називають «lockdown generation», тобто «поколінням локдауну». За прогнозами МОП, для молодих людей виникають ризики бути виключеними з ринку праці або відкладення виходу на ринок праці у зв'язку з коронавірусом.

Розвиток нових професій. В наступних роках будуть розвиватись нові професії на ринку праці, а застарілі, або зникати, або ж видозмінюватись. Відбудеться розквіт логістичних професій у сфері доставки (кур'єри). Розвитку набудуть спеціальності в cфepi digital (цифрові маркетологи, онлайн фасилітатори). Також збільшиться попит на програмістів: аналітиків 3 інформаційної безпеки, розробників програмного забезпечення, веб-розробників, IT-аналітиків, експертів з BigData. Буде потреба в антикризових менеджерах, експертів з HR та цифрової трансформації. Зросте попит на психологів, особливо на тих, хто переорієнтується на онлайн формат праці. Необхідним залишиться медичний персонал, особливо висококваліфікований. А постраждають найбільше представники турагентств, ресторанів та готелів, салонів краси та фітнес клубів, через відсутність роботи.

Висновки. В сучасних умовах виживають та розвиваються тільки ті компанії, які можуть швидко підлаштовуватися під постійно мінливі умови зовнішнього середовища, ефективно працювати в умовах високої невизначеності. Гнучкість організацій, приватних осіб та суспільства - обов'язкова умова адаптації в посткоронавірусному світі. Особливо це стосуватиметься, звичайно, працівників. Необхідно буде не тільки підлаштовуватися під організаційні зміни, а й бути готовими вчитися новим навичкам і набувати нового досвіду в будь-якому віці, пробувати себе в інших ролях і навіть перекваліфікуватися в середині кар'єрного шляху. Для багатьох співробітників професійна мобільність, безперервна перепідготовка та зміна робіт стане основним способом досягти маневреності, зберегти зайнятість або принести користь суспільству.

На внутрішніх ринках праці відбувається суттєва зміна організації робочих місць та робочого часу. Це потребуватиме релевантного узгодження систем оплати праці та правил і норм дистанційної роботи для запобігання порушення норм тривалості робочого часу та підтримання оптимального балансу «робота - життя». На перше місце HR-стратегій виходять стратегії гнучкого використання людського ресурсу, програми безпеки та гуманізації праці (well-being programs), цифровізація бізнесу та окремих HRпроцедур.

На національних ринках праці посилюється роль держави не тільки як регулятора нових, гнучких форм зайнятості, але й захисні функції на ринку праці шляхом запровадження програм компенсації збитків постраждалому бізнесу (кредитні та податкові канікули, зниження чи відміна деяких податкових зборів, прямі трансферти) та вивільнюваним працівникам (допомога по повному та частковому безробіттю, допомога у працевлаштуванні та перенавчанні).

В глобальному вимірі відбувається пришвидшення процесів роботизації та цифрової трансформації бізнесу, структурних зрушень на ринках праці: зменшення частки малокваліфікованих робітників виробництв та збереження частки 
інтелектуального, креативного класу, переосмислення методів організації спільної офісної роботи, доцільності залучення до робіт трудових мігрантів. Означені тенденції потребують подальшого моніторингу та досліджень.

\section{СПИСОК ВИКОРИСТАНИХ ДЖЕРЕЛ}

1. Пашкіна, Т. (2020, 16 вересня). Ситуаџія на ринку праџі може повернутись до весняних показників у разі другої хвилі коронавірусу. Гордон.юа http:https://gordonua.com/ukr/news/money/situatsija-na-rinku-pratsi-mozhe-povernutisja-dovesnjanih-pokaznikiv-v-razi-drugoji-hvili-koronavirusa-ekspert-1518646.html

2. Державна служба зайнятості (2020, 10 грудня). Аналітична та статистична інформація. https://www.dcz.gov.ua/analitics/68.

3. KPMG (2020, 18 жовтня). Дї̈ HR в ситуаиї пандемії. Звіт за результатами опитування KPMG в Україні. https://home.kpmg/ua/uk/home/insights/2020/05/hr-actions-in-pandemicsurvey.html

4. Філіпчук, Л., Ломоносова, Н. (2020, 25 вересня) Коронавірус $і$ дистанційна робота: щ⿻о зробила держава. Аналітичний центр CEDOS. https://www.cedos.org.ua/uk/articles/koronavirus-idystantsiina-robota-shcho-zrobyla-derzhava

5. Савоскіна, К. (2020, 30 травня) Тимчасові працівники, бронювання робочих місиь та колективний біг онлайн. Умови прачі після карантину. Громадське https://hromadske.ua/posts/timchasovi-pracivniki-bronyuvannya-robochih-misc-ta-kolektivnij-bigonlajn-umovi-praci-pislya-karantinu

6. Zakaria, F. (2020) Ten Lessons for a Post-Pandemic World. First Edition. USA: W.W. Norton \& Company, Inc.

7. Кориди, Т. (2020, 10 вересня) Ценности и культура: как полюбить компанию в эпоху digital. Презентація на конференції Smart HR Online Marathon. https://youtu.be/NsldfcGc8ZQ

8. Лібанова, Е. (2020, 7 квітня) Вірус демократії сильніший за коронавірус. Головний украӥнський демограф Елла Лібанова про Украӥну $i$ світ $y$ вирі пандемії. НВ. https://nv.ua/ukr/ukraine/events/koronavirus-v-ukrajini-i-pandemiya-u-sviti-interv-yu-demografa-provirus-i-demokratiyu-novini-ukrajini-50080562.html.

9. Kozlovskyi, S., Bilenko, D., Kuzheliev, M., Lavrov, R., Kozlovskyi, V., Mazur, H., Taranych, A. (2020). The system dynamic model of the labor migrant policy in economic growth affected by COVID-19. Global Journal of Environmental Science and Management, 6 (Special Issue (Covid-19)), 95-106. doi: 10.22034/GJESM.2019.06.SI.09.

\section{REFERENCES}

1. Pashkina, T. (2020, 16 September). Sytuacija na rynku praci mozhe povernutys' do vesnjanyh pokaznykiv u razi drugoi' hvyli koronavirusu. Gordon.jua https://gordonua.com/ukr/news/money/situatsija-na-rinku-pratsi-mozhe-povernutisja-do-vesnjanihpokaznikiv-v-razi-drugoji-hvili-koronavirusa-ekspert-1518646.html

2. Derzhavna sluzhba zajnjatosti (2020, 10 December). Analitychna ta statystychna informacija. https://www.dcz.gov.ua/analitics/68

3. KPMG (2020, 18 Octpber). Dii HR v sytuacii pandemii. Zvit za rezultatamy opytuvannja KPMG v Ukraini. https://home.kpmg/ua/uk/home/insights/2020/05/hr-actions-in-pandemic-survey.html

4. Filipchuk, L., Lomonosova, N. (2020, 25 September) Koronavirus i dystancijna robota: shho zrobyla derzhava. Analitychnyj centr CEDOS. https://www.cedos.org.ua/uk/articles/koronavirus-idystantsiina-robota-shcho-zrobyla-derzhava

5. Savoskina, K. (2020, 30 May) Tymchasovi pracivnyky, bronjuvannja robochyh misc' ta kolektyvnyj big onlajn. Umovy praci pislja karantynu. Gromads'ke https://hromadske.ua/posts/timchasovipracivniki-bronyuvannya-robochih-misc-ta-kolektivnij-big-onlajn-umovi-praci-pislya-karantinu 6. Zakaria, F. (2020) Ten Lessons for a Post-Pandemic World. First Edition. USA: W.W. Norton \& Company, Inc. 
7. Korydy, T. (2020, 10 September) Cennosti i kultura: kak poljubit kompaniju v jepohu digital. Prezentacija na konferenciï Smart HR Online Marathon https://youtu.be/NsldfcGc8ZQ

8. Libanova, E. (2020, 7 April) Virus demokratii' syl'nishyj za koronavirus. Golovnyj ukrainskyj demograf Ella Libanova pro Ukrai'nu i svit u vyri pandemii. NV. https://nv.ua/ukr/ukraine/events/koronavirus-v-ukrajini-i-pandemiya-u-sviti-interv-yu-demografa-provirus-i-demokratiyu-novini-ukrajini-50080562.html

9. Kozlovskyi, S., Bilenko, D., Kuzheliev, M., Lavrov, R., Kozlovskyi, V., Mazur, H., Taranych, A. (2020). The system dynamic model of the labor migrant policy in economic growth affected by COVID-19. Global Journal of Environmental Science and Management, 6 (Special Issue (Covid-19)), 95-106. doi: 10.22034/GJESM.2019.06.SI.09.

Середа А.В., кандидат экономических наук, Донецкий национальный университет имени Васыля Стуса, ORCID: 0000-0001-9222-1887

g.sereda@donnu.edu.ua

Магас Н.А., Донецкий национальный университет имени Васыля Стуса

mahas.m@donnu.edu.ua

ПРОГНОЗИРОВАНИЕ БУДУЩИХ ИЗМЕНЕНИЙ НА РЫНКЕ ТРУДА УКРАИНЫ В РЕЗУЛЬТАТЕ ПАНДЕМИИ СОVID-19

Статья посвящена оценке состояния рынка труда и прогнозированию будущих изменений в сфере труда под влиянием пандемии коронавируса. В результате анализа зарубежных и отечественных источников информации, статистических данных показателей запланированного высвобождения работников, показателей зарегистрированного и фактической безработищы в Украине, сделан вывод, что пандемия COVID-19 приведет к глобальным изменениям на рынке труда, в характере труда, а потому работодателям и работникам нужно адаптироваться под новые условия жизнедеятельности. Для этого обозначены основные направления этих изменений и продемонстрированы лучшие практики адаптации предприятий к ним. Доказано, что карантинные меры вызвали более интенсивное сокращение малоквалифицированного персонала, в основном, рабочих профессий, и необратимые процессы распространения дистаниионной формы организаиии труда. Это потребует дальнейшего нормативного регулирования дистанционной работы, интенсификации программ переквалификации высвобождаемых человеческих ресурсов, усиления их сочиальной защиты, поддержки работодателей, особенно малого бизнеса, в период коронакризы.

Ключевые слова: рынок труда, безработииа, удаленная работа, иифровизаиия, COVID-19.

H. Sereda, PhD in Economics, Vasyl Stus DonNU, ORCID: 0000-0001-9222-1887

g.sereda@donnu.edu.ua

M. Mahas, Vasyl Stus DonNU

mahas.m@donnu.edu.ua

\section{DEVELOPMENT OF AGRICULTURE OF UKRAINE IN THE CONTEXT OF GLOBAL FOOD}

SECURITY

The article is devoted to assessing of the state of the labor market and forecasting future changes in the field of labor under the influence of the coronavirus pandemic. As a result of analysis of foreign and domestic sources of information, statistics on planned layoffs, registered and actual unemployment in Ukraine, it was concluded that the COVID-19 pandemic will lead to global changes in the labor market and the nature of labor, and therefore employers and employees need to adapt to new living conditions. The main directions of these changes are outlined and the best practices of adaptation of enterprises to them are demonstrated in this research. It is proved that quarantine measures have led to a more intensive reduction of low-skilled personnel, mainly working professions, and irreversible processes of spreading the remote form of workplace organization. This will require further regulation of distance work, intensification of retraining programs of released human resources, strengthening their social protection, support of employers, especially small businesses, during the coronary crisis.

Key words: labor market, unemployment, distance work, digitization, COVID-19 